\title{
-Review-
}

\section{Origin and Ancestry of Native Horses in Eastern Asia and Japan}

\author{
Ken NOZAWA
}

Faculty of Liberal Arts, Chukyo University, 101 Tokodate, Kaizu-cho, Toyoda-shi, 470-03 Japan

(Received 1 May 1992)

The domestication of the horse, like that of other farm animal species, should be understood as a gradual process, but in the period of about 3,000 BC this process is considered to have developed remarkably in the grassland areas of Southeast-Europe. In the process of dispersion of the domesticated horses to the east, particularly up to the period of establishment of the Mongolian native horses, some gene-flow is considered to have possibly occurred from the wild Przewalsky horses to the domesticated stock.

The origin of the Southeast Asian and Japanese native horses is undoubtedly the Chinese native horse. The Chinese native horses are classified into two types with different body size: the Mongolian horse and the Southwest mountain pony. Both of these two types are considered to have been more or less influenced genetically by the Arab-Persian horses introduced from the west. The phylogenetic interrelationship between the two types of Chinese native horses should be clarified by comparative examinations of the two. It is possible that the Southwest mountain pony is only a dwarf type of the Mongolian horse, which has been adapted to draft and pull uses in mountaineous environment of the area.

The small-sized native horses raised in a wide area of Southeast Asia have evidently originated from the stock of the Chinese Southwest mountain pony, and since then have been more or less genetically influenced by the West-European horses in and after the epoch of western colonization.

The native horses raised in Northeast Asia, namely Korea and Japan, are considered to have mainly originated from the Mongolian horse. The breeding history of the Cheju native horses, Korea, suggests this fact. The reality of the theory that the small-sized horses in Okinawa and Amami Islands of Japan have originated from the Chinese Southwcst mountain pony is questionable, because this theory has been founded on the inference that the horses have been raised since the Jomon period of Japan including the Southwest Islands, namely Okinawa and Amami island chain. Recent archeological excavations show that horse breeding in Japan began in the Kofun period. If this is correct, it is more reasonable to consider that the Mongolian-typed horses had been imported for the first time into Japan in the Kofun period through the Korean peninsula. Then, the small-sized native horses in the Southwest Islands of Japan are postulated as a dwarf type of the Japanese native horses which originally came from the mainland. Final clarification of this point waits for the accumulation of excavation data of horses the living age of which are ascertained chemically.

Key words: ancestry, excavation domestication, native horse, phylogeny

Jpn. J. Equine Sci. 3(1): 1-18, 1992 


\section{東亜と日本在来馬の起源と系統}

\section{野澤 謙}

中京大学教盖部 T470-03 愛知県豊田市貝津町床立101

目次

1. はじめに：日本在来馬について

2. ウマの家畜化と東亜在来馬の成立

3. 日本在来馬の起源と系統

4. 摘要と結び

\section{1. はじめに：日本在来馬について}

最初に在来馬 (native horse, indigenous horse) を定義して沶きたい。17-18 世紀，産業革命を目 前にひかえたイギリスを中心とするョーロッパに， 限定された育種目標に向って人為選抜と近親交配 とを併用して家畜や作物の品種 (breed) を造成す るという方式の㕕種事業（breeding）が発足した。 これを契機にして, 各家畜種にそれぞれの利用目 的に応じた高能力品種が相次いで誕生し, 現代に 至るまで人類はその恩恵に浴している。1859年に 刊行されたダーウインの進化論はこうした時代思 潮の産物にほかならず，ウマに括いても競走馬サ ラブレッド (Thoroughbred) を始めとする諸馬種 がこの方式によって育種され，品種として確立さ れた。在来家畜とはこうした近代的育種から影響 を受けることがなかった，あるいは受けることが 少なかった家畜群であり, 地域集団とか地方集団 (local population) の名で呼ばれている。わが国 には明治の開国以来, この西欧的育種思想が流入 し，あるいはこのようにして育種された家畜品種 が導入され, 交雑され, 在来種の改良が押し進め られた。和牛のごときはこらして育種された品種 であるから，これを在来牛とは呼び難い。日本在 来馬は明治の開国以前からわが国で飼養されてき たウマの直接の子孫であって，その多くは育種学 的意味では改良度の低い地域集団である。 現在, 日本国内に飼われている在来馬は, 図 1
に示す 8 馬種である。これらはいずれも今世紀初 頭以来, 太平洋戦争終結まで主として陸軍の軍用 馬改良政策をのがれて各地方に残存維持されてき

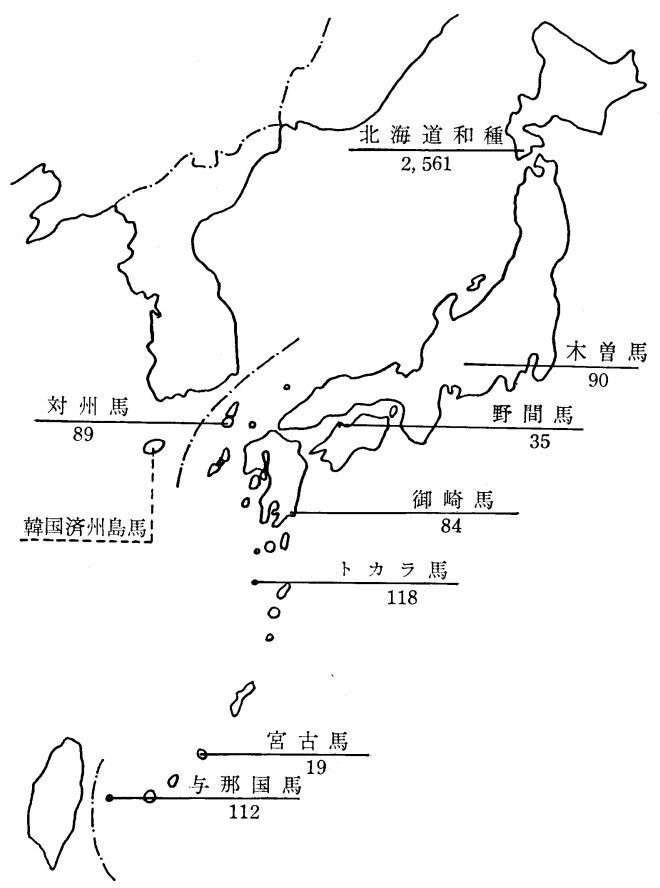

図 1. 日本在来馬の飼育原産地と飼養頭数（1991 年 9 11月現在；日本馬事協会，1991）

Fig. 1. Feeding places and populations of the Japanese native horses (As of Sept.-Nov., 1991, Japan Equine Assoc., 1991) 
た農馬の集団に属する。現頭数（日本馬事協会， 1991）が図中に記入されているが，総頭数 3,000 頭余りであり，その $80 \%$ 北海道和種が占め, 他 の馬種はいずれも 100 頭内外かとれ以下の頭数で ある [68]。これら在来馬種の成立の経緯について, 古くは松本(1948)[54]，岡部(1953)[83]，林田， 山内 $(1955,1956)[28,29]$ ，林田，日越 $(1961)[26]$ が馬種ごとに記述して拈り，近年になって日本馬 事協会 (1981，1985）[66,67]は全在来馬種を網羅 した単行書を刊行した。

軍事と競馬を除いたウマの用途は農耕と運輸で あったが，わが国では戦後の急速なモータリゼー ションの結果, ウマの農業的用途は注とんぞ消隇 した。農用馬の全国頭数は 2 万頭前後に過ぎない。 その中の $15 \%$ 余りを在来馬 8 馬種が占めているが, これらを保存することの意義の第 1 は全地球規模 で要請されている動物遺伝資源保持のためであり, 第 2 に国あるいは地方の文化遺産を守り，次代に 承け継ぎ，その系譜を明らかにするための素材と してである（野澤，1986）[79]。1970年代には農 業的需要の衰退によって各馬種とも減数著るしく, 存続が危ぶまれたが，郷土の文化財としての保存 に熱意を然やす，主として地もと民有志の努力に よって飼養頭数はここまで回復したのである。こ れら 8 馬種のらち, 北海道和種, 木曾馬, 対州馬 には血統登録がおこなわれ（日本馬事協会, 1991） [68]，品種化への道を歩んでいると認めることが できる。

このような日本在来馬はどこに源郷をもち，い つ，どのようにしてこの国土に家畜馬として定着 するに至ったか，についての諸説を概観すること が本総説の目的である。いま“諸説”と言ったが, 事実これまで何人かの家畜学者, 考古学研究者, 文化史家がこの問題に関心をもち，たがいに相容 れない諸説を提出し論争が怙こなわれた。それら をできる限り公平に紹介して問題点を指摘した上， 現在の知識段階ではどのような考え方が最も合理 的と考学られるかについて，この問題に関心と興 味をもつ家畜研究者の一人としての筆者の見解を 提示したい。

\section{2. ウマの家畜化と東亚在来馬の成立}

家畜化 (domestication) を動物の生殖に対する
人為的管理が強化されていく過程であると定義 (Herre and Röhrs, 1971 [35]; Mason, 1973 [52]; 野澤, 1975 [75]; Nozawa, 1980 [76]）すると, 各 家畜種とも家畜化の時期を厳密に特定することは 原理的に困難であり，かなりの時間幅をもった推 測で満足しなければならない。それでも，ウマに 関しては諸家の見解にさほど大きなひらきはなく, 大体 $\mathrm{BC} 3,000$ 年前後の時期と言われる（加茂, 1937 [40]; Herre, 1958 [33], 謝, 1959 [88]; Zeuner, 1963 [103]; 芝田, 1969 [87]; Bökönyi, 1974 $[3,4]$; Herre and Röhrs, $1977[36]$; CluttonBrock, 1981 [8])。主要農用動物（牛, 水牛, 馬, 驢, 豚, 山羊, 羊, 犬, 鶏) の中ではウマの家畜 化は最も遅れている。

家畜化の場所については見解がわかれる。初期 の研究者には, 現代馬が複数の地域で家畜化され た野生馬に由来するとの見解をもつ者が多かった。 特にヨーロッパに生息した tarpan に起源をもつ 欧州馬と, アジア大陸中央部に最近まで野生して いた Przewalsky 馬の家畜化に由来する蒙古馬と の少くとも 2 系統が想定されていた (Keller, 1919 〔45]; 吉田, 1926 [102]; Wagner, 1926 [97〕; 加茂, 1937[40]; 芝田, 1969 [87])。曾って, 野生馬 (Equus ferus あるいはE. przewalskii) の分布 域は, 東は中国東北部から中央アジア, カスピ海 や黒海の北岸, 中欧を経て西はイベリア半島に至 る太いベルト状をなしていた (Herrs and Röhrs, 1977 [36])。tarpan が家畜馬の再野生化型である との推測 (Nobis, 1955 [71]; Herre, 1958 [33]) も あり, 最近の研究者の多くは, ウマの最初の家畜 化を南東ヨーロッパ, ウクライナのステップ地帯 を中心とするトリポリエ(Tripolje) 文化が拈こな ったと推測する (Herre and Röhrs, 1971, 1977, 1990 [35-37]; Herre, 1972 [34]; Zeuner, 1963 [103]; Bökönyi, 1974, $1984[3,4])$ 。出土遺骨の 状態から, 家畜化の最初には肉が食用とされてい たと見られている。中国の家畜史家，謝（1959） [88]は中国北部の草原地带で中国人の祖先が Przewalsky 馬を家畜化したのが世界最古の家畜 馬であると主張するがこれは今のところ少数意見 である。

東アジアは技そらく，図20ルート1によって 家畜馬を受け入れたと考学られるが，このルート 


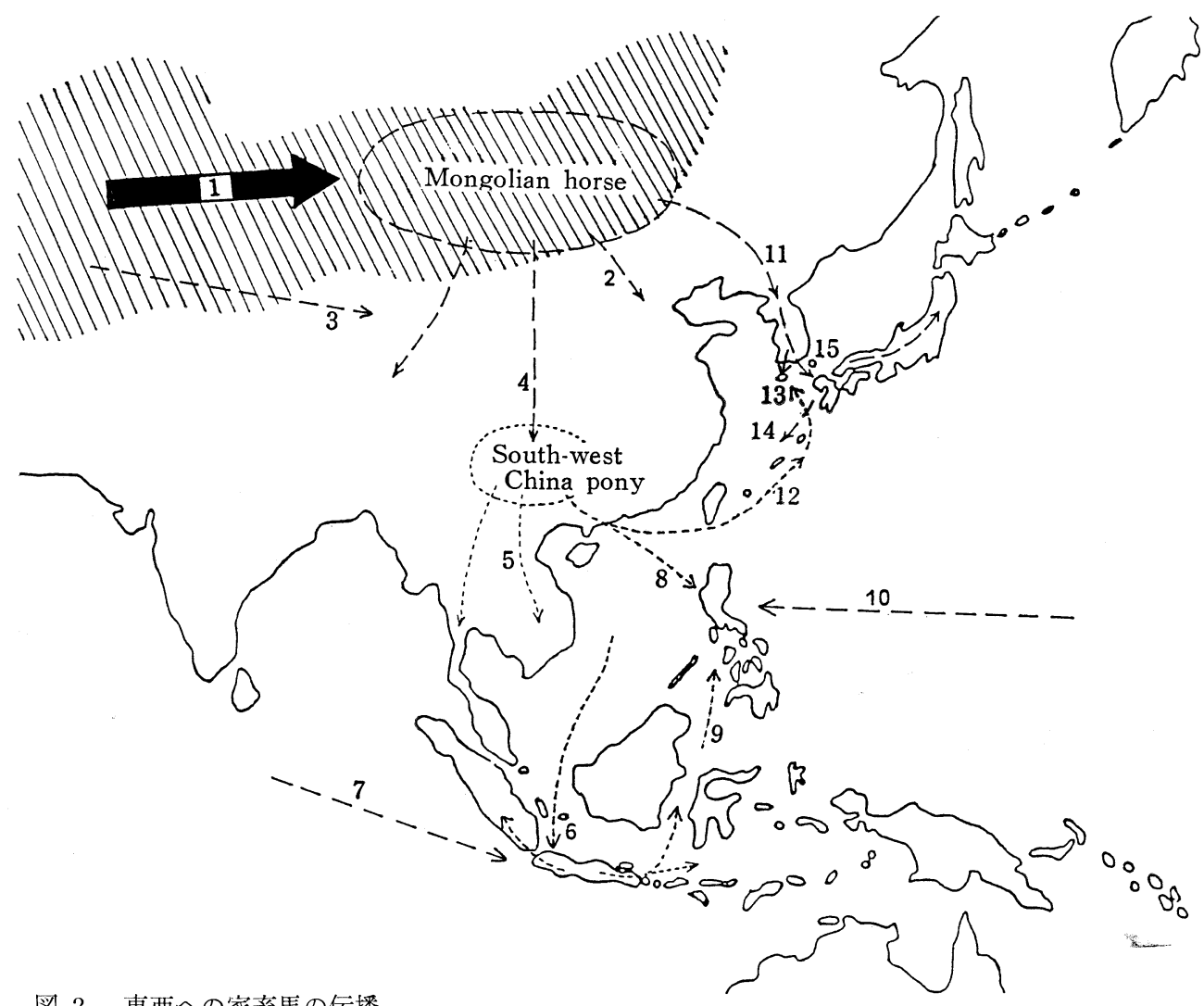

図 2. 東亚への家畜馬の伝播 斜線部は野生馬の分布域（これは Herre and Röhrs，1977 による)，ルート番号1-15は本文参照.

Fig. 2. Dispersion of domestic horses to East Asia Hatched area is distribution range of the wild horse (Herre and Röhrs, 1977). For explanation of route numbers (1-15) refer to the text.

は困に示されているよらに野生馬の分布地域と重 なる。家畜馬の東への伝播の過程で Przewalsky 野生馬から家畜馬への遺伝子流入 (gene-flow) が あった可能性は無視できない。現代の蒙古馬が Przewalsky 馬に近い体型をもつことが中国が独 自かつ最初にウマを家畜化したとの主張の根拠に なっているが，この遺伝子流入によって体型的類 似性が生じているのかも知れない。

現在，野生馬はヨーロッパ地域では完全に絶隇 している (Zeuner, 1963) [103〕が，アジアの Przewalsky 野生馬の方は, 野生状態でこそほぼ 消滅したと見られるものの，世界各国の動物園に 少頭数づつ飼育されている。1985 年 1 月現在で 134 飼育場所飞雄合計 260 頭, 雌合計 348 頭が飼 育中と報告されている（Volf, 1986)[96]。Mohr (1971) は飼育下での Przewalsky 馬の形態や生 態を紹介する書を刊行して扮り[59]，国連食糧農
業機構 (FAO) は家畜遺伝子源保護の一環として, 飼育下にあるこの野生馬を保護すると共に，これ を彼等の自然生息環境へ帰して保存する計画を推 進中である (FAO，1986)[17]。

この飼育 Przewalsky 馬の染色体の調査が括こ なわれた結果，興味深い事実が明らかになった。 家畜馬の染色体数が $2 n=64$ であることは古くか ら知られていたが，Przewalsky 馬では $2 \mathrm{n}=66$ であり，両者の間の $\mathrm{F}_{1}$ は $2 \mathrm{n}=65$ で生殖力をも つというものである (Benirschke et al., 1965 [2]; Koulischer and Frechkop, 1966 [48]; Short et al., 1974 [89]; Matthews and Delhanty, 1979 [56])。 このあと，モンゴリアの在来馬，すなわち蒙古馬 12頭の染色体があらためて調べられたが，すべて が $2 \mathrm{n}=64$ であった (De Schepper et al., 1979) 〔11〕。また，村松らは家畜馬として日本在来馬 8 馬種合計 100 頭と, Przewalsky 馬として東京都多 
摩動物園に飼育されているモウコノウマ 1 頭とを 用いて染色体の比較調查を打こなったが，日本在 来馬はすべて $2 \mathrm{n}=64$, モウコノウマは $2 \mathrm{n}=66$ であった（村松ら，1984，1990）[63，64]。上の観 察結果はすべて, Przewalsky 馬の acrocentric 常 染色体 2 対が，家畜馬に拈いては Robertson 型 転座を抗こして submetacentric 常染色体 1 対に なっている。

これらの研究結果は, Przewalsky 馬を家畜馬 の野生原種に擬する立場（例觉ば謝，1959）【88〕 にとっては明らかに不利である。しか乙野生馬と 家畜馬の間の $\mathrm{F}_{1}(2 \mathrm{n}=65)$ が生殖力を有してい るとすると, $F_{1}$ が $2 \mathrm{n}=64$ の家畜馬と交雑して その後, 家畜馬集団の中で世代が重ねられたとの 推測，すなわち Przewalsky 馬から家畜馬集団へ の遺伝子流入が扣こった可能性をこの染色体調査 の結果から完全に否定することはできない。 $F_{1}$ の生殖力が完全に正常であったとしても，転座を 扤こしていない 2 本の染色体が機会的に失われて 転座した 1 本の染色体の久で集団が占められてし まう可能性がある。細胞学的には $F_{1}$ の生殖力す なわち適応度は野生馬, 家畜馬双方の適応度より 劣ることが予測される (De France, 1979, De Boer, 1979)[10,11]。もしそうであれば，ここに 集団遺伝学の淘汰理論に括ける負の超優性 (negative overdominance) 機構が働いて, 集団中に染 色体多型が長く維持される可能性はなく, 頻度の 低い型, この場合は Przewalsky 馬の転座してい ない 2 本の常染色体は急速に除去されてしまうと 考えられるからである。

ウシやオナーゲルを模倣してウマに車を率かせ るといらアイディアが生まれたのが BC 2,000 年 紀の初めであり，これが馬戦車 (chariot) の方向 に進化してウマは生物兵器となる。騎乗 (riding) もまたウマで最初に開発された技術ではなく, 近 東地域ではウシやゾウの騎乗が以前から打こなわ れていた (Downs, 1961)[13]。ウマにこれが初 めて応用された時期が BC 2,000 年紀の終末期, 場所はクリミアの北にひろがる草原地帯, 騎馬術 の開発はやがてスキタイ文化 (Scythians) の担い 手となる遊牧民達によってなされたと考えられる。 以後 3,000 年を超える長期間にわたって, ウマは 軍の基幹兵器の一つであり続け, 外征に関心をも
つ諸民族はこの兵器を採り入れ, ウマの育種改良, 馬具の開発整備, 騎乗者の養成訓練を吝ることが なかった。農地の耕作や物資の輸送にウマを使役 することは確かに重要な用途であるが，軍事的用 途に比べればマイナーであると言わざるを得ず， 特殊な気候条件下にある地域を除く全世界への家 畜馬の伝播も，侵寇軍の動力源がウマであったこ とに注㴆せられる。史家の加茂（1937）が述べ ているように，古代文明圈がウマを自主的に採り 入れた例はかつてない〔40]。かならずその地が外 部からの軍事侵略にさらされたときにウマが現わ れるのであって，このことは家畜としてのウマの 性格をよく表わしている。BC 1,700 年前後には， インダス文明を破壊したアリアン民族が北からイ ンド亜大陸にウマをもたらした。中国では，黄河 流域に $\mathrm{BC} 1,500$ 年ごろ羁を唱えた殷王朝は戦車 を持っていた。その王墓には馬骨と青銅製の戦車 とが合葬されている。 BC 3 世紀の末，中原を制 した秦は北方騎馬民匈奴の侵寇に備兄て万里の長 城を建設した。秦の後を継いだ漢の武帝は，黄河 流域と西域との間の交易路の開拓と, 西域の良馬 の獲得といら事蹟によって名高い。BC 2 世紀末, 武帝は 2 度にわたって大宛（フェルガナ, 現在の トルキスタン) へ遠征軍を送り，そこで，天馬， 汗血馬, 千里馬などと呼ばれるアラビア,ペルシァ 系の駿馬を手に入れた。漢民族の戦士はこれを乗 りこなすことによって蒙古系馬に乗る匈奴と対抗 することができた。このフェルガナに至る道がシ ルク・ロードとなるのであり, これが東の漢帝国 と西のローマ帝国とを結びつける。

武帝のこの事蹟から，その頃すでに家畜馬に，

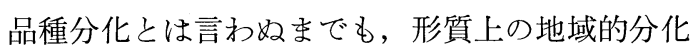
が生じていた事実，東亜在来馬の源郷である中国 の馬産が，北の蒙古馬（図 2 ルート2）ばかりで なく、ヨーロッパの馬産の基礎ともなった中近東 地域の馬飼養文化からも影響を受けてきたといら

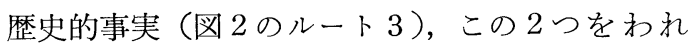
われは知ることができる。

東亜全域の在来馬の系統的センターが中国大陸 の在来馬集団であることに誰しも異論はない。た た，中国在来馬には少なくとも 2 つ類型がある。 中国馬の生物学的記載について, 戦前には Phillips and Moyer (1945)[86]が，戦後は Epstein (1969) 
〔16〕が全家畜を紹介する著作を出版し，その中で ウマの記述にも応分の紙数を費している。しかし， これらはウマの各地域集団の特徴を羅列的に記載 するにとどまり，その系統的分類への言及はほと んどない。こうした記載よりも，何人かの中国人 研究者の著作の方が系統論的概観を与兄るには適 している。かような文献として謝（1959)[88]，

Sieh and Wang (1979)[91]，鄭（1980)〔6]，お よび Cheng（鄭，1984)[7]を挙げることができ る。この最後の 2 つよると, 中国在来馬は次の 3 つの生態型にわけられる。

北部草地馬：蒙古系馬（体高 $127-136 \mathrm{~cm}$ )

西北高原馬：甘肃，青海，四川各省にまたがる 河曲馬（体高平均 $140 \mathrm{~cm}$ )

西南山地馬 : 雲南, 貴州両省の在来馬（体高平 均 $115 \mathrm{~cm}$ 前後)

このうち, 西北高原馬 (河曲馬) は Sieh and Wang (1979)[91]によるとペルシァや中央アジ ア由来のアラブ系馬種の遺伝質を多分に混じ，そ のため大型化していると言われるから, 中国固有 の在来馬は蒙古系馬と西南山地馬とに 2 大別され ると考劣るこができる。前者は乾燥した北部草 原での乗用馬であり, 後者は降雨量の比較的多い 山地での駄用㧍よび輓用馬である（鄭，1980； Cheng, 1984)[6,7]。さらに西位するチベット 高原の在来馬は蒙古系馬と西南山地馬の中間の体 格を有している。また最近は西南山地馬の類型に 含まれると考兄られる，体高 $1 \mathrm{~m}$ に充たぬ「果下 馬」の一地域集団が広西省南部で発見され, 保存 の途が講じられた（王，1990 a, b) [98, 99]。これ らのほか, 中国各地にいくつかの改良育成品種が あり, 鄭（1980）は三河馬, 伊犁馬, 金州馬, 黒 龍江馬, 吉林馬および鉄嶺輓馬の 6 馬種を挙げて いる[6]。これらは蒙古系馬に主としてロシア系 改良馬が交配され作出された地域集団とみなされ る。

上に挙げた諸馬種のらち, 西南山地馬の起源に ついての研究例は少ない。これと同類型のウマが 広く東南アジア一帯に飼養され利用されているに もかかわらず，これまでヨーロッパの家畜系統史 家 (Zeuner [103], Herre [33], Bökönyi [4]な ど）の注目を受けることはほとんどなかった。謝 （1959）の「中国養馬史」によれば，西南中国に
括ける養馬の発展は秦, 漢時代 (BC 200 年ごろ 以降）飞始号，宋朝期（960 年以降）に北から の馬匹資源流入の道が杜絶したため，その前の唐 朝期には重視されていなかった西南馬が重要な国 防資源となったという〔88]。この記載が事実であ れば，西南山地馬は蒙古系馬の一分枝で, 山地で の駄載と輓用を主とする用役に適応して体格が矮 小化したに過ぎないとも考光られる（図 2 ルート 4 )。

しかし, 日本や中国の何人かの研究者が，中国 西南山地馬は蒙古系馬とは別個独立の家畜化に由 来するとの見解を公にしている。すなわち，吉田 （1926）によれば，非漢系の先住民が有史以前に 山間部に生息していた小型の野生馬を捕獲家畜化 し，その後漢民族の圧迫を受けて西南山地にウ マを伴って後退していったと言う〔102〕。森為三 （1930）もPrzewalsky 野生馬とは別に中国山地に は小型の野生馬が生息し, 四川, 雲南, 貴州各省 の矮馬は後者の家畜化により生まれたと推測して いる[62]。さらに最近では, 余 (Sieh, 1982) が 歴史記録, 出土物の考古学的研究, 環境条件とウ マの生態的形態的特徴などを考慮して, 蒙古系馬 と雲南在来馬とが別個の家畜化に由来し, 相互間 に系統関係はないとの主張を括こなっている[90]。

こうした見解や主張は, 歴史記録や出土遺骨か ら得られる情報のみを根拠にしておらり, 遺伝育種 学的裏付けに乏しいし，特にウマの体格に变異が 見られると直ちにとれに近似した体格をもつ野生 馬に起源を求めるといら古典的研究方法にとらわ れているとの感を禁じ得ないのが事実である。し かし，上記のよらな主張がある以上，これを一つ の仮説としてその当否を近代生物学の方法を用い て検証する試みがなされるべきであろら。

タイ国，ミャンマー，インドシナ半島の在来馬 は中国の西南山地馬に起源をもつと考えられる (Manit, 1961〔51]; 林田, 大塚, 1974〔27])。現 在な拉, タイ拉よびインドシナ半島北部の少数民 族は, ウマを伴って中国西南山地の非漢系少数民 族と交流を保っている(図 2 ルート 5 )。

インドネシアの在来馬は Merkens (1926) によ れば 7 世紀前半, ジャワの土候が中国からウマを 入手したのに始まるといら〔57〕。13-14 世紀には 元 (モンゴル) 騎兵の侵寇を受け（図 2 ルート6), 
次いでヒンズーやアラブの侵入があり，さらにこ の島嶼地域はオランダの植民地となったので，そ の間，アラビア系执よび西欧系馬種から遺伝質が 混入している可能性がある（図 2 ルート 7 )。山 根（1943)[100]は Merkens (1926)[57]に従っ て，インドネシア在来馬を，スンバ馬，スンバワ 馬，チモール馬，サヴー馬，フローレス馬，ロン ボック馬, バリ馬, スマトラ馬, セレベス馬, ジャ ワ馬の10品種に分類しているが，これらを品種と 呼ぶことには疑問があり，地方集団と考えるべき であろら。

フィリッピン群島の全域で馬車率き用に使役さ れている小型馬 (Philippine pony) もまた中国西 南山地を源郷とするウマを華南（図 2 ルート 8), あるいはインドネシア方面から（図 2 ルート9） 手に入れ，それに执そらくはアメリカ統治時代に 新大陸経由で導入された西欧系馬種の遺伝質を多 少とも混じた（図 2 ルート10）集団と考えられる (Mackie, 1916 [50]; Montemayor, 1958 [60])。

以上，東南アジアの大陸部と島嶼部一带に飼育， 利用されている在来馬はすべて平均体高 $115 \mathrm{~cm}$ 程 度の中国西南山地馬とほぼ同大の体格をもつか, さもなければ，アラビア系，西欧系馬種の遺伝質 を多少とも混じているものでは，これより数 $\mathrm{cm}$ 程度大きい平均体高值をもつ。こうした生物学的 根拠からばかりでなく，歴史記録が物語るその地 の在来馬成立の経緯から見ても，これら馬種の源 郷が中国西南山地にあることに疑いを容れる余地 はいまのところない。

日本在来馬種の成立に大きな影響を与えたに違 いないと考えられる朝鮮半島とその附属地域の在 来馬の起源と系統はどのよらに考觉られているの であろらか。姜（1965）[41]によれば，朝鮮（韓 国）の在来馬は体格により胡馬と郷馬に分けられ る。前者は平均体高 $130 \mathrm{~cm}$ を越える，いわゆる中 型馬で，北朝鮮に飼われ，蒙古馬の系統につらな ることが明らかな馬種であり（図 2 ルート 11）, 後者は平均体高 $115 \mathrm{~cm}$ 前後の済州島馬（この現況 については済州大学校，1985[5]）で，韓本土に も飼われているが，産地はもっぱら済州島である。 これの起源について森為三 (1930) は四川矮馬 (中 国南山地馬） $\rightarrow$ 日本石器時代矮馬（日本南西諸島 在来馬） $\rightarrow$ 朝鮮矮馬（済州島馬）の伝播経路（図
2 ルート 12，13）を想定した［62］。林田，山内 （1956）もまた日本，韓国を始めとする東亜諸地 域馬の体尺測定值の比較研究の結果から同様の推 定をおこなった[30]。これに対し，植村（1937） は済州島には有史以前からウマが飼養されていた 可能性はあるが，済州島に本格的馬産が興ったの は高麗朝が元に服属（13世紀後半）して以後であ ることを歴史記録から推論した〔95]。姜 (1965, 1970） [41，43]もこの地の馬産が歴史記録上明嘹 に確認できるのは1258年以後で，済州島が馬産地 となったのは高麗朝忠烈王 3 年（1277年）に，元 が植民と共にウマを北方より導入し，この島に牧 場を設置してから以後であろらと推定した。最近 日本で覾訳出版された済州島の歴史書 (金, 1969) もほ注同様の史実を伝えている[46]。

姜（1970）は元が持ちこんだ馬種はアラブ系の 遺伝質を承け継いだ大宛馬であろらと考光ており [43]，他の研究者（森 [62]，植村 [95]，金 [46]） は蒙古系馬であると想定している。いずれにして も当時済州島に導入され，この地の馬産の基礎と なったウマは体高 $130 \mathrm{~cm}$ を越える「中型馬」で あったと考えざるを得ない。とすると，済州島馬 が現在見るような矮小な体格をもっているのは何 故であるか（姜，1970）を疑問とせざるを得ない [43]。朝鮮矮馬は曽ってはより大形であったもの が，不良な飼料飼養事情や，良馬が官馬に徵集さ れたために扢こった逆淘汰のために退化，小格化 したのではないかとの推測があるが，かような説 は「机上ノ空論想像説デ，科学的二何等拠儿所」 はない，といらのが森為三（1930）の所論である [62]。

日本の在来家畜研究者は韓国の同学者の協力を 得て，特に遺伝学的方法によって済州島馬の現地 調査を扣こなった（野澤，1970； Nozawa and Kondo, 1970)[73，80]。まず体尺測定值において は，韓国本土で使役されている済州島馬は済州島 内のそれに比べ，雄の体高において平均 $5 \mathrm{~cm}$ 程 度大きく，この差は統計学的にも高度に有意であ る。このことはすでに発表されている李（1961） [49]や姜（1965，1966）[41,42]の測定結果と同 様である。また主遺伝子（major genes）に支配 されるメンデル形質である毛色や血液型の遺伝子 頻度に扣いては，韓本土と済州島集団との間に大 
差はない。日本在来馬と比較すると，トカラ馬や 琉球在来馬のようないわゆる小型馬とは著しい 差異が認められる反面，北海道和種や木曽馬のよ らないわゆる中型馬に近い頻度分布を示してい る。こうした調查結果から，野澤（1970）[73]， Nozawa and Kondo (1971)[80]は森為三 (1930) によって「机上ノ空論」とされた〔62]産馬の小格 化が果してあり得ないかを考察した。もし済州島 にもともと小型馬が飼われて括り，13世紀に中型 馬が導入され交雑されたとすれば，集団中の遺伝 的変異性は增大寸るから，その後に㗢らく淘汰圧 への反応性は大となるはずである。済州島は韓国 で唯一の馬産地で, 産馬の雄は本土に移出され使 役されてきた。その際，比較的大型のものが移出 され，小型のものが島に残って繁殖に供されるこ とがあり得る。琉球馬にこの実例があり（野澤， 1967）〔72〕，済州島馬については上述のごとくこ れが実証されている。これが世代を重㸚て続けら れると，体格に関する逆淘汰が働らくであろう。 いま移出雄馬と全生産雄馬との間の平均体高差を $x \mathrm{~cm}$, 雄馬の移出率を $\mathrm{e}_{\mathrm{m}}$, 体高の平均遺伝率を $\mathrm{h}^{2}$ とすると, $\mathrm{t}$ 世代後の生産雄馬の体高の変化 $\mathrm{R}_{\mathrm{t}}$ は,

$$
\mathrm{R}_{\mathrm{t}}=-\frac{1}{2} \mathrm{t} \cdot \mathrm{h}^{2} \frac{\mathrm{e}_{\mathrm{m}}}{1-\mathrm{e}_{\mathrm{m}}} \cdot \mathrm{x}
$$

で与えられる。 $\mathrm{t}$ を牧場開設年の1277年から1967 年までの約 700 年，ウマの 1 世代を 8 年とすると 90世代となる。蒙古馬の平均体高を $140 \mathrm{~cm}$, 現在 の済州島馬のそれを $110 \mathrm{~cm}$ （前者をやや過大に， 後者をやや過小に仮定する）として $\mathrm{R}_{\mathrm{t}}=-30 \mathrm{~cm}$ としょう。 $\mathrm{h}^{2}$ の值にいるいろな值を入れ，雄の 移出率 $\mathrm{e}_{\mathrm{m}}$ と, 上記一 $30 \mathrm{~cm}$ の体高変化を抏こすに 必要な平均体高差 $\mathrm{x}$ との関係を図示したのが図 3 である。調査当時 $\mathrm{e}_{\mathrm{m}}$ は0.7-0.8である。 $\mathrm{h}^{2}=0.3-$ 0.5 と仮定すれば $\mathrm{x}=0.3-0.9 \mathrm{~cm}$ となる。すな わち, 韓本土に移出される雄馬が済州島で生産さ れる全雄馬の平均值より $1 \mathrm{~cm}$ 足らず体高が大で あれば，この島に牧場がひらかれて以来約 700 年 間に産馬の体高が $30 \mathrm{~cm}$ 程度減少することは充分 に可能である。調查当時の実測では生産地・済州 島と使役地・韓国本土とで雄馬の平均体高差は約 $5 \mathrm{~cm}$ に達する。このことは逆淘汰による済州島 馬の小型化が必ずしもあり得ぬことではないこと

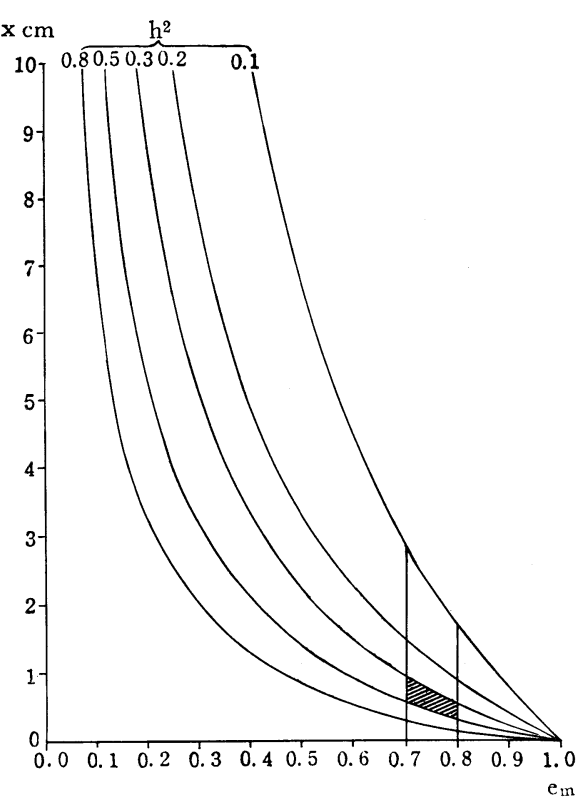

因 3. 関係式 $\mathrm{R}_{\mathrm{t}}=-\frac{1}{2} \mathrm{t} \cdot \mathrm{h}^{2} \frac{\mathrm{e}_{\mathrm{m}}}{1-\mathrm{e}_{\mathrm{m}}} \cdot \mathrm{x}$ によって雄 馬の移出率 $\mathrm{e}_{\mathrm{m}}$ と, 移出雄馬, 全生産雄馬間の平均体 高差 $\mathrm{x}$ との間の関係を示寸図

$\mathrm{R}_{\mathrm{t}}: \mathrm{t}$ 世代後の済州島馬と蒙古馬の平均体高 差, $\mathrm{t}$ : 世代数, $\mathrm{h}^{2}$ : 体高の遺伝率

(Nozawa and Kondo, 1970)

Fig. 3. Relation between values of $\mathbf{e}_{\mathrm{m}}$ (emigration rate of males) and $x$ (difference in mean withers height between emigrant males and all the males born), as calculated by the formula: $R_{t}=-\frac{1}{2} t \cdot h^{2}$ $e_{m} /\left(1-e_{m}\right) \cdot x$, where $R_{t}$ is change in withers height after $t$ generations and $h^{2}$ heritability of withers height (Nozawa and Kondo, 1970)

を意味している。

\section{3. 日本在来馬の起源と系統}

日本最古のウマの化石として，岐阜県可児郡平 牧村（現在は可児町内）の第 3 紀中新世の地層か ら, ウマの右下顎断片と左下顎の第 3 小目歯が出 土している。発見者の松本彦七郎はこれらをとラ マキウマ(Anchitherium hypohippoides) と命名 し，三趾馬であるとした。「日本古代家畜史」（芝 田，1969）にはこの例をはじめ，上部洪積世まで の地層から合計16例のウマ化石の出土が記載され ている。多くは洪積層上部から沖積層下部にかけ てのものであるが，旧石器にともなわれた出土例 はない[87]。それゆ光，地質時代のわが国土内に 
ウマが野生していたことは疑いないものの，それ がいつの時代まで生存していたのか，われわれ日 本人の祖先がそれを資源として利用したことが あったか，あったとすればその利用のしかたにつ いては直接的証拠なしの推測による判断がでさる に過ぎない。

経済史家の鑄方（1945）は新石器時代遺跡から 出土するウマの遺骨を家畜馬だと断定することは 危険であろうと指摘している[38]。実際，大家畜 を飼うといらアイディアをもつに至った時期に， 日本国内に野生馬が生息していたとすれば，われ われの祖先はそれを狩猟する以外に，飼う，馴ら すという試みをしたかも知れない。しかし，新石 器時代まで野生馬がわが国に生息していたと推測 する古生物学者, 考古学者は汪とんどいない。古 代獣骨の専門家である直良（1984）もまた「洪積 世末……本は大陸から離れて現在のような列島 となった。大陸日本の廃絶と共に，日本における 地質時代の馬の歴史は終止符をうった。古沖積世 の当初, 約 2,000-3,000 年間は野馬の棲息してい ない日本であった。……私（は）……島となった 日本には, 地質時代の野馬の遺存種や後裔などが 棲んでいて，これが後に前期縄文文化期の古代人 に飼養されるようになったのではあるまいか，と 考えていたこともあった。だがとれから……今日 （まで），その証拠となるような資料の発見は一つ もなかった。やはり馬の無棲息時代があったこと を認めなければならないことになった」と述べて いる[65]。縄文前期に家畜馬がいたと推測してい る直良でさえこのように考えるとすれば，日本の 野生馬がこの国土内で家畜化された可能性は極め て小さいであろら。そうであるとすれば，わが国 は，いつか，どこからか，家畜馬を受け容れたと 考学なければならない。

日本へのウマの渡来時期を推定する根拠となり 得るいくつかの事実と記述がある。

（1）日本の縄文・弥生両期の遺跡からウマの遺 骨が出土する。芝田（1969）によれば計75個所, 北海道から沖縄に及び，縄文前期の例もあるが， 縄文後晚期から弥生期の例が多い〔87]。

（2）わが国に馬戦車が渡来した形跡はない。史 書 (Eberhard, 1980) によると，中国大陸で戦車 が盛に使われていた殷代は BC 1, 100 年ごろまで
であり，西周から春秋時代に入る BC 500 年ごろ 初めて騎兵が出現し, 戦車を置き換える[14]。 従って, 日本へのウマの渡来はこの時期以後と考 えられる。

（3） AD 3 世紀（弥生末期）のわが国状を記録 した「魏志倭人伝」には「無牛馬虎豹羊鵲」と記 されている。

（4）馬具や埴輪馬の出土はもっぱら古墳期に 入ってからである。従ってわが国内でウマの飼養 が史料的に確認できるのは古墳期以後となる。

さて，日本の古代馬に注目した初期の研究者に 長谷部（1925）がいる[20]。彼はいくつかの遺跡 から出土するウマの四肢骨の大きさから体格を推 定し, わが国石器時代には出水 (鹿児島県, 縄文 後期), 田結 (長崎県, 弥生期) 出土例のような 体高 $115 \mathrm{~cm}$ 内外, 体重 $200 \mathrm{~kg}$ 以下の小型馬と, 平 井 (愛知県, 縄文後期), 鴨井 (神奈川県, 弥生 期）出土例のような体高 $130 \mathrm{~cm}$ 内外，体重 $280 \mathrm{~kg}$ 程度の中型馬がいたと推定した。この研究を馬学 専門家の立場で発展させたのが林田（1956[21]， それ以後)である。彼は集められる限りの古代馬 の四肢骨を測定し, みずから案出した公式（林 田, 山内, 1957）により体高を推定した[32]。長 谷部のいら通り, 日本古代馬には小型, 中型の 2 型があったが，注目すべきは，縄文遺跡からは小 型馬が, 弥生以降の遺跡からは小型, 中型の両型 が出土する。また林田（1957）は新田義貞の鎌倉 攻略戦（1333年）で死没した多数の人馬の骨を含 む鎌倉材木座遺跡の馬骨を測定し，体高の推定を おこなったところ，109-140 cm の間に分布し，小 型馬と中型馬とが混在していた（図 4)〔22〕。林 田はこの時代以降, 明治の開国まで日本馬の体格 は打拈よとこの範囲に分布していたであろらと推 測している[22]。

林田 (Hayashida and Yamauchi, 1956[31]; 林田，1958[23]）は日本と東亜の在来馬の測定 データ（高嶺，1948〔48]；松本，1953〔55]；岡 部, 1953 [84]；三村, 1953 〔58〕）の収集も広く未o こなった。北海道和種, 木曽馬, 御崎馬は平均体 高 $132 \mathrm{~cm}$ 内外で中型馬, トカラ馬, 宮古馬, 与那 国馬など南西諸島一帯の在来馬は体高 108-122 $\mathrm{cm}$ で小型馬である。対州馬は両型の中間である。 また東亜各地の在来馬を体高によって中型, 小型 


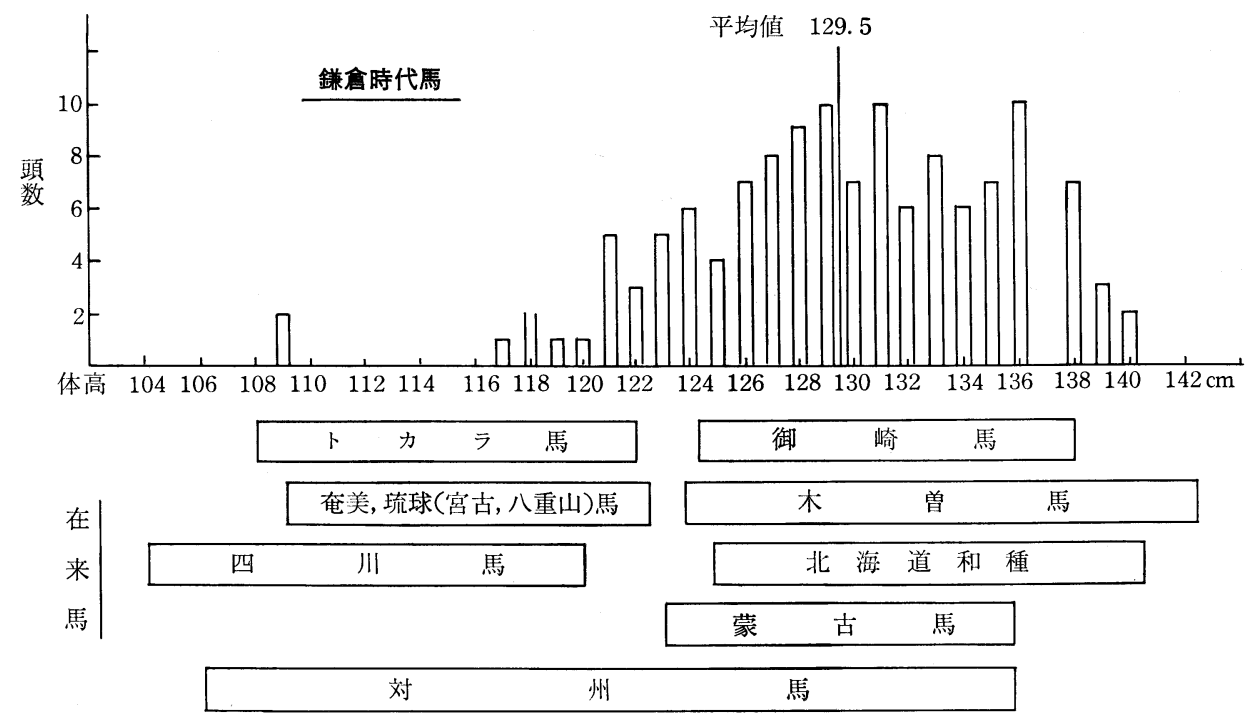

図 4. 中世鎌倉時代馬の推定体高と在来馬の体高の範囲（林田，1968）

Fig. 4. Distribution of the estimated withers height of horses in Kamakura era of Japan, and ranges of withers height of East Asian native horses (Hayashida, 1968)

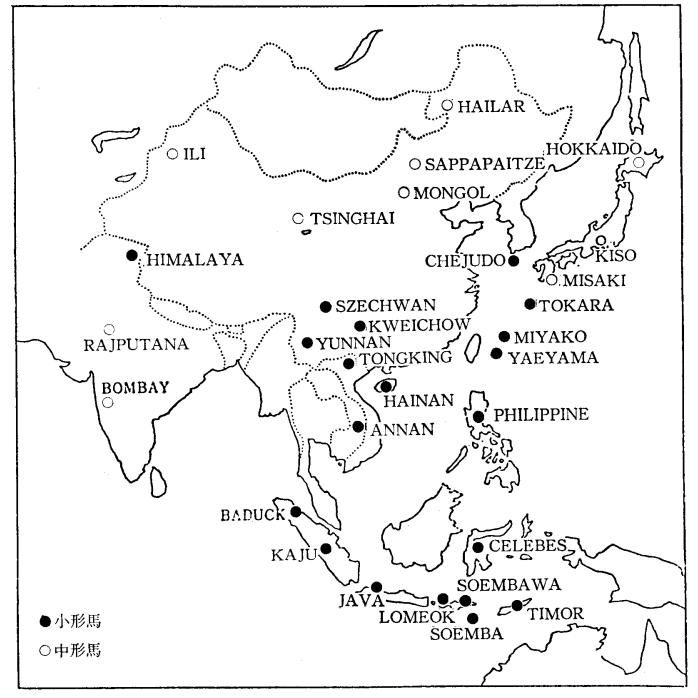

図 5. 東亜に拈ける小型馬と中型馬の分布（林田, 1968)

Fig. 5. Distributions of small-sized and medium-sized native horses in East Asia (Hayashida, 1968)

にわけ地図上に示すと図 5 のようになる。中国大 陸の長城線以北は蒙古馬の影響の強い地域で, そ この在来馬は中型であり, 華南から東南アジア一 帯は小型馬の分布地域である。以上の事実と東亜 古代馬に関する文献記録とから，林田は日本在来 馬の源流について次のような想定をおこなった
[24，25]。すなわち，中国の四川，雲南から華南 一帯にかけて, 現在の四川馬の基礎となった小型 馬 (果下馬) が古くから飼われていた。これが縄 文後晚期から弥生期にかけ，華南沿岸から黒潮飞 乗って，九州と南朝鮮に入った（図 2 ルート12）。 次いで弥生期から古墳期にかけて, 中型馬が朝鮮 半島からわが国に導入された（図 2 ルート15）。 これら 2 型のウマは国内で交雑したが，有史以来， 軍事運輸の必要から小型馬は減少し，鎌倉時代に は中型馬が多数を占め，汇戸末期，明治初期には 小型馬は土佐駒として残り，他は木曾馬，御崎馬 のような中型馬のみとなった。九州南西諸島には 小型馬しか入らなかったので, トカラ馬, 与那国 馬などとして残った，というのである（林田， 1964，1968)。

日本が縄文後晚期以降, 最初に南西諸島経由で 小型馬を, 次いで朝鮮半島経由で中型馬をと, 2 波にわたって大陸からウマを受け入れたとする林 田の学説は, 前述した森為三（1930）の推論[62] に近いものである。この研究は, 単にウマがいた, いなかったといらにとどまらず， ウマの生物的形 質に注目し，それを基礎にして系統論の構築を試 みているのであって, 以後の日本在来馬のみなら ず，在来家音研究への有力な指針となった。

しかし, 森・林田学説にも問題がないわけでは 
ない。そもとも体格のみを標識にして系統論を構 成することが可能であるか，といら疑問が生まれ る。相互に血縁など考兄られない遠隔の地に多く の小型馬種 (pony) が散在している事実 $[18,19]$ をどう説明すればよいのであろらか (Flade, 1981; Flade and Gless, 1989)。韓国済州島馬について 前節に引用した Nozawa and Kondo (1971) の理 論は，小型化の可能性を示すにとどまるが[80]， 小型馬として最も名高い Shetland pony は北海 に浮かぶ島嶼環境で小型化したものであり (Flade, 1981）〔18〕，体高 50-70 cm といら超小型馬 Falabella 種はアルゼンチン国内で育種されたもので ある (Flade and Gless, 1989) [19]。ウマに限ら ず小型家畜の育種の成功例は決して少くない（例 えばミニブタの育種, Dettmers et al., 1965[12〕)。 逆に, 日本小型在来馬の典型とみなされるトカラ 馬の平均体高は原産地トカラ群島宝島から鹿児島 大学農学部入来牧場に移されると僅か $2-3$ 世代 で雌雄とも 3-4 cm の増大を示している（小山田 ら，1979；柳田ら，1985）[85，101]。すなわち， ウマの体格は飼養条件によって変化するし, 人為 淘汰, 自然淘汰にさらされれば容易に遺伝的变化 をも抗こし得るのである。こうした形質を系統解 明のための標識として使用すると, 詋った結論 に導びかれる危険性が高いのではないか。野澤 （1983）は在来馬を材料にして，各種標識形質の 系統論的研究への適合性について論議している [78]。

遺跡から馬具が古墳時代に入ってから出土し始 めることは, わが国で発掘調査が開始されて以来 よく知られていた。民族学者の江上波夫がこの事 実のら它に立って, 騎馬民族日本征服説を発表し たのは, 1948年 5 月, 東京で他の 3 人の民族学者 と共にもった座談会に扣いてであった。後にこ の学説は「騎馬民族国家一日本古代史へのアプ ローチ」(1967) と題する著書として公刊されて いる[15]。

わが国の弥生時代に続く古墳時代は 4 世紀初頭 から 7 世紀末までの約 400 年間であるが，江上は これを前期 100 年と後期 300 年とに分けた。まず 古墳という築造物が, 前期では丘陵の頂上近くに 作られた, 小さく簡単な構造であるのに対し, 後 期に入ると, 応神陵, 化德陵のような平地に作ら
れた壮大な前方後円墳が多くなり，広い墓室をも ち, 壁面に装飾のあるものが少くない。副葬品を みると，前期古墳では鏡，剣，玉，鈥形石，車輪 石など宝器的，象徵的あるいは呪術的な意味を もった，平和な農耕民的色彩の強いものである。 それに対し, 後期に入ると武器, 食器, 馬具など 実用的な道具でありながら，華麗で戦闘的，王侯 貴族的なものが多くなる。前期古墳時代の文化が, 弥生文化の継続として理解できるのに対して, 後 期のそれは, 当時東北アジアから朝鮮半島まで広 がっていた騎馬民族文化の性格をそのままに示し ている。かような急激な変化は, 前期の農耕民が 自主的に異文化をとり入れて自己の伝統文化を変 化させたとは考光にくく，大陸北方の騎馬民がわ が国に侵入，征服し，支配権を握ったとしか考兄 られない。このとき日本国家の統一が成しとげら れたのであり，大和朝廷とはこの騎馬征服者に よって樹立された政権であったというのが汇上の 主張である。

この騎馬民族説は, 史学・考古学分野でよく知 れた事実を基礎にし，日本建国といら事件を大陸 の文化や政治動向々関連づけて提出されたものだ けに，多くの議論を呼び起こした。賛成者と共に 反対者もいる。この説の批判者には, 文化の移動 とヒトの移動とは別ではないか, 特に朝鮮半島か ら征服者が侵入したのではなく，逆にこちらから 朝鮮へ向けての軍事行動の結果，騎馬術を含め先 方の文物をとり入れたのではないかと考兄る研究 者が多いし，多くの人馬が征服行動として日本に 侵入したとすれば，それを運ぶ船舶を問題にする 柳田国男のよらな批判者もいる。日本における階 級分化，特に皇室の成立は弥生時代にさかのぼり， 4,5 世紀の渡来者はいわゆる帰化人で，この人 々が騎馬を導入したとは考光られても，支配者と なったとは考光にくいといらのが後藤守一の反対 論である。ウマの立場からい党ば，後期古墳から 埴輪馬は数多く出るが, 出土馬の生物的形質が 5 世紀初頭あたりを境にして大きく変化したとの確 認も合意もない。特に水野祐が論じているように， 騎馬民族がウマを伴って侵入したとすれば，彼等 がまず定着した九州や大和にウマの遺体や埴輪馬 の出土が多いはずである。ところが馬骨と埴輪馬 の出土例の圧倒的多数は関東地方からであり, 西 


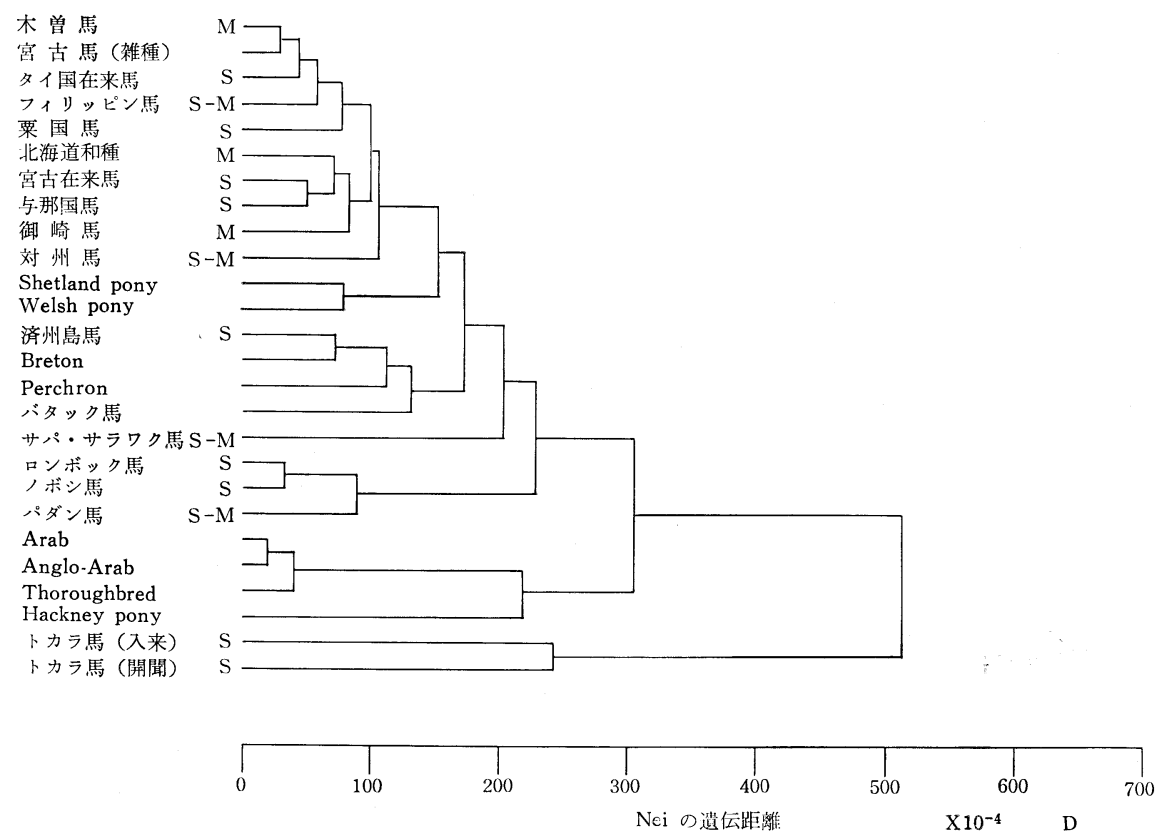

困 6. 多座位電気泳動法による日本と東覀の在来馬 および西欧系馬種相互間の遺伝距離マトりッ クスから描かれた枝わかれ図

$\mathrm{S}$ は小型馬，Mは中型馬， S-Mはその中間の体格であることを示す.

Fig. 6. Dendrogram of Nei's genetic distance among East Asian and European horses drawn by the result of multilocus electrophoresis of blood proteins

S: small-sized, M: medium-sized, and S-M: intermediate between small-sized and mediumsized horses

Japanese \& Asian native horses (18 populations)

Shetland pony \& Welsh pony

Percheron \& Breton

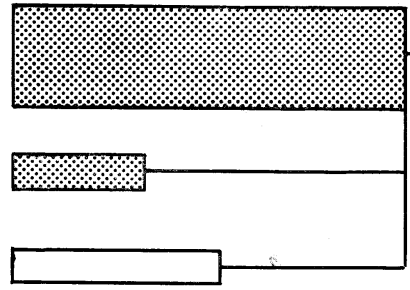

Arab, Anglo-Arab $\&$ Thoroughbred

Tokara horses (2 populations)
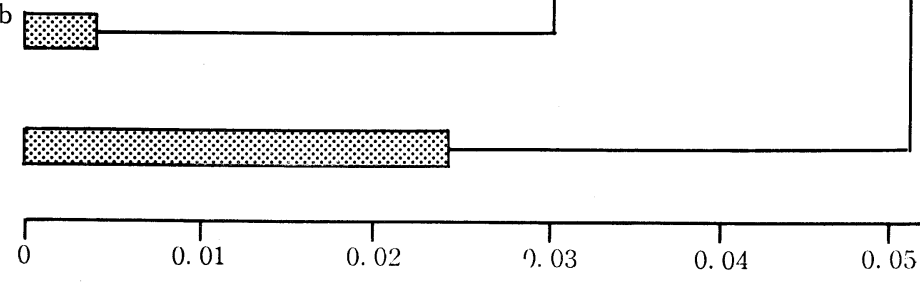

Nei's genetic distance (D)

図 7. 図6 の結果を簡約化して描いた諸馬種の遺伝的類似性 (Nozawa, 1983 を若干改変)

Fig. 7. A simplified figure showing genetic similarities among various populations of horses (modified from Nozawa, 1983) 
日本に馬文化の痕跡はきわめて微弱である点をど ら考えるべきか，といらのが水野の問いである。 騎馬民族説に対する種々の批判は，鈴木編「論集 騎馬民族征服王朝説」（1975）飞集めら孔ている [92]。

騎馬民族説が論議を呼んだ要点はその王朝征服 説にあり, 馬具や埴輪馬の出土が 5 世紀以後に集 中しているという事実に疑問をはさむ研究者は少 い。また史実上，ウマの飼養が確認されるのは 5 世紀以降であることから，わが国に拈ける馬飼養 が古墳期に始まったと考光る研究者は多い。もし そうであれば，前述した「魏志倭人伝」の記述と も矛盾しない。こうした場合，3世紀以前の日本 には実はウマもウシもいたのだが，倭人伝の著者 はそれを見逃したのだろらと片づけてしまらのは 問題であろら。

日本と東亜在来馬の系統を, 淘汰に対する中立 性が保証されている形質を使って解明する試みが なされるべきである。Nozawa et al. $(1975,1976)$ は血液蛋白の多座位電気泳動法 (multilocus electrophoresis）によって馬種間の遺伝的比較を抏こ なっている[81，82]。調べている遺伝子は血液中 の酵素拉よび非酵素蛋白をコードする約 30 遺伝子 座であって, 各馬種についてそれらの座位の遺伝 子頻度を電気泳動の結果から計算し, 馬種間の差 を遺伝距離 (genetic distance) で表わす。調べた 馬種のすべての対にたいして遺伝距離が算出され るが，その值の小さな対から順次まとめ上げてい く操作 (clustering) を繰返せば，図6のような枝 わかれ図 (dendrogram)を描くことができる。こ れは1983年段階までの調査結果である。これを簡 約化して描いた諸馬種間の遺伝的類似性を図 7 に 示す (Nozawa, 1983)[77]。

これを見ると，まず日本のトカラ馬が他から大 きく離れた遺伝子構成をもっていることがわかる。 これはトカラ馬の遺伝的変異性が著しく低いため で，これはこの馬種が現在まで何度か集団サイズ の縮小 (bottle-neck) を経験してきたためであ る。集団遺伝学に括ける遺伝子頻度の機会的変動 (random genetic drift) の「後遺症」を意味し, メンデル式主遺伝子を標識として家畜の系統の解 明を目ざす場合，ときどきこれがあらわれて， データに雑音 (noise) を混入させる。遺伝学的研
究方法の欠点に数兄られるべき性格と言えるかも 知れない。

トカラ馬以外の諸馬種の集団内遺伝的変異性は ほぼ同一レベルにあり，多型遺伝子の頻度差によ る比較が可能である。図 6 をみると，日本や東亜 の在来馬, Shetland, Welsh など西欧系ポニー, 特よび Perchron, Breton など西欧系重輓馬が一 つの大枝の中に含まれ，Arab, Thoroughbred な ぞの競走馬が他の大枝を作っている。このことは 競走馬諸馬種がアラブ系馬種の血統を共通に承け ていること，共通祖先とされる野生馬 tarpan 由 来の遺伝子の多くを保持しているといら古くから 唱えられてきた推論を裏づけているのかも知れな い。

問題は日本と東亜の在来馬である。このうち, 与那国馬, タイ国在来馬, 宮古馬, 済州島馬, 口 ソボック馬などは小型馬に相当する体格, 北海道 和種, 木曽馬, 御崎馬は中型馬, フィリッピン馬, 対州馬などは小型と中型の中間の体格である。体 格と遺伝子組成との間飞相関関係はまったく認め られない。また，これらのウマの中で，与那国馬 や宮古在来馬は林田（1968)[25]が中国の四川, 雲南両省を源郷として南から日本に最初に入って きたと想定した小型在来馬である。一方，タイ国 在来馬といらのは実は中国雲南省の在来馬で，山 地少数民族が山伝いに南下してタイ国北部に持ち 込んだもの，あるいはその子孫，つまり中国西南 山地馬そのものである。それ故, 林田学説が正し ければ，与那国馬や宮古馬と共に他の馬種からは 離れた一つのクラスターを作りそうなものである。 図6にはそのような傾向はうかが光ない。

日本や東亜の在来馬はかなり多様な遺伝子構成 をもった馬種群である（図 7)。そして全体とし て日本在来馬は，小型馬であろうと中型馬であろ うと，たがいにかなり近い遺伝子組成を有してい ることを図 6 は示している。小型と中型という 2 つの型を遺伝的に区別できないとすると，日本が アジア大陸から 2 波にわたって別系統のウマを受 け入れたといら遺伝的証拠がないことになる。証 拠がないことをもって，問題の事実を否定する根 拠とすることはできないが，図 6 のよらな分析結 果は, 日本が大陸, 招そらくは朝鮮半島から 1 波 のウマ渡来を受け入れたと仮定しても十分に説明 
がつく。その場合，トカラ馬，宮古馬，与那国馬 など日本南西諸島の小型馬は, 本土から南下し, 小島嶼に隔離されて小型化した集団であると考光 られる（図 2 ルート14）。沖縄には神馬伝説があ る。史書には騎馬術を日本より学んだとの記述が 見られ，絵巻などには騎馬が盛んに打こなわれて いたことが示されている。14-15 世紀に沶ける琉 球王朝の中国明朝への朝貢貿易に打いて，ウマが 重要な輸出品であったことも史実に明らかで，こ れらは小型馬であったらしい（當山，1979）[94]。

さて, 森・林田の日本在来馬 2 波渡来説に拈い ても，江上の騎馬民族説に打いても，遺跡からの 出土品の紀年が学説の基礎として重要な意味をも っていることは明らかである。特に，わが国の縄 文期, 弥生期に多くの馬骨が出土するとされてい ることを前に述べたが，考古学研究者の多くがこ の点に疑問をいだいている。例えば森浩一(1974) は，確かに縄文や弥生の遺跡から馬骨は出ている けれぞも，それぞれの遺跡の年代の包含層から出 ている例は少く，上く見ると，貝塚や遺跡に後か ら穴を掘って埋めたものが多い。従って，こうし た例はすべて再検討が必要であり, 特に遺骨の化 学的な生存年代推定を抏こならことが望ましいと 述べている[61]。河口，西中川（1985）は鹿児島 県下の出水貝塚，沖縄県の宇宿貝塚のような縄文 遺跡や，鹿児島県下の弥生期のものとされる高橋 貝塚から，いずれも馬骨が出土すると報告されて いるが，層序的にみてほんとうに当時のものであ るかに疑問が残るとしている[44]。安里（1985） も琉球王の中国明朝への主要貢物の一つがウマで あったことは，沖縄グスク期（12-15 世紀） 飞盖 馬が普及していたことを示唆するが，沖縄へのウ マの導入は朝貢開始期を大きく遡るものではない と考光られ，先史時代にウマはいなかったと述べ ている 11$] 。$ 李朝実録の中世琉球資料（15 世紀） も同じことを暗示しているように見劣る（野澤， 1971) $[74]$ 。

西中川とその協同研究者（西中川ら，1989, 1991）は，古代遺跡からの馬骨，埴輪抢よび土馬 のこれまでの出土例を全国調査によってすべてり ストアップする試みをおこなった が出土した遺跡数は延べ数にして合計 587, うち 229 が関東地方にある。合計延べ数のうち縄文期
57, 弥生期 34, 古墳期 110 , 残り 386 は奈良朝期 以後の遺跡である。埴輪馬の出土数は全国合計 297，らち170は関東地方で，これらはすべて古墳 期である。また土馬（土製馬と馬形土製品）は合 計589，万ち328が近畿地方，特に奈良県と京都府 に集中し，奈良時代と平安時代の古都からの出土 が目立って多い。埴輪馬が関東に多いのは，東北 地方の蝦夷勢力に対抗するために騎馬隊を保有し ていたことを示唆するのではないか，また奈良県 や京都府の古都から土馬の出土例が多いのは，当 時の政治的動きと関係があり，特に祭祀に用いら れたためであろらと推定している（上村，1991） [39]。

問題は馬骨が出土した縄文期や弥生期の遺跡で あるが，「これら先人の報告は ${ }^{14} \mathrm{C}$ などの年代測 定もなされておらず，後世の混入」や「攪乱層か らの出土が多く，確実に時代を特定できるものは ごく少ないようである。」(西中川ら，1991)[69]。 また近代的手法によっておこなわれた発掘で，縄 文期，弥生期から馬骨が出土した例はない（西中 川ら，1991)[69]。すなわち，確実な年代推定が できる出土馬骨はすべて古墳期以後のものといら ことになる。なお，出土馬骨の測定値から，林 田，山内（1957）の方法〔32]で体高を推定すると 最低 $109 \mathrm{~cm}$ ，最高 $139 \mathrm{~cm}$ の間に分布し，平均值は $126.4 \mathrm{~cm}$ である。そして小型のウマが古い遺跡に 多い傾向が認められる。

千葉県野田市にある縄文遺跡の大崎貝塚から， 1986年，シカ，イノシシなどと共に馬骨が出土し た。従来，縄文時代にウマが存在するとされてい たのに，近年は精密で大規模な発掘が拈こなわれ ているにもかかわらず，馬骨の出土例がないので， 近藤ら（1991）はこの大崎貝塚出土馬骨中の弗素 を分析し年代判定を試みた〔 47$]$ 。結果，この 骨は伴出したニホンジカやイノシシの骨に比べ弗 素含有量は著るしく低く, 同時代のものとは考光 られない。すなわち後世の混入であると判断され た。同様の結果は他の縄文貝塚出土馬骨について もすでに得られているといら。松井（1992）は, 縄文, 弥生時代のウマの出土例はいくつかあるが, 地域的にも時期的にも孤立的で，その系統をたど ることは不可能であり, 今後, 骨の化学的分析に よって生存年代の判定をおこない, 考古学的出土 
状況に誤りがないかを検討する必要があるとして いる[53]。実際，近藤ら（1991）[47]も述べてい る通り, ウマの存否は当時のヒトの生活様態や文 化的系譜を理解しようとするときに，欠かすこと のできない重要な課題であろう。

\section{4. 摘要と結び}

ウマの家畜化は，他種家畜のそれと同様，漸進 的な過程として理解しなければならないが，BC 3,000 年前後に，東南欧の草原地带を舞台にして， この過程は大きく進展したと考えられる。この家 畜化中心地から東に向方家畜馬伝播の過程, 特に 蒙古馬成立に至るまでに，Przewalsky 野生馬か ら遺伝子が流入した可能性がないとは言えない。

東亜と日本の在来馬の源流は疑いもなく中国在 来馬であるが，中国在来馬には体型を異にした蒙 古系馬と西南山地馬の 2 大類型があり，これらに， 西域経由で導入されたアラブ・ペルシア系馬種が 多かれ少なかれ遺伝的影響を与えている。中国在 来馬の 2 大類型間の系統的関係については，それ らの間の遺伝学的比較調查を招こなうことによっ て明らかにされよう。「2大類型」と言われては いるが，西南山地馬が蒙古系馬が単に山地環境で の駄載と輓用を主とする用役に適応して生じた矮 小化型に過ぎない可能性もないとは言光ない。

大陸部，島嶼部を問わず東南アジアの広域に分 布する小型在来馬が，中国西南山地馬の系統につ らなることに疑問の余地はいまのところない。こ の地域の現在の産馬は，植民地化の歴史のなかで, 西欧系馬種の遺伝的影響を多少とも蒙っていると 考えられる。

東北アジア，すなわち韓国や日本の諸在来馬種 は主に蒙古系馬の系統につらなると考えられる。 韓国済州島馬成立の歴史はこれを示唆して拈り, この馬種の成立の初期以来, 小型化して現在に 至っているという可能性がある。日本在来馬のう ち南西諸島の小型在来馬が中国西南山地馬に由来 するとの説については，この説が，縄文・弥生両 期に，南西諸島を含む日本に馬産があったという 推測に根拠を置いているところから見て，疑いな きを得ない。最近の考古学的発掘が，日本に括け る馬産が古墳期以降に始まったことを物語ってい るとすれば，古墳期に朝鮮半島を経由して種々の
文物を受け入れるなかで, 蒙古系馬が輸入され馬 産が始まったと推測する方がより合理的であろう。 その場合, 南西諸島の小型在来馬はもと本土より 南下し，小型化したものと考えられる。ただし， この点については, 遺跡から出土した馬骨の生存 年代を化学的方法によって明らかにしたデータが 蓄積するのを待って最終的判断を下すべきである。

\section{引用文献}

1. 安里嗣淳 (1985). 沖縄グスク時代の文化と動物. 季刊考古学 $11: 68-70$.

2. Benirschke, K., Malouf, N., Low, R.J., and Heck, H. (1965). Chromosome complement : differences between Equus caballus and Equus przewalskii, Poliakoff. Science 148 : 382-383.

3. Bökönyi, S. (1974). History of Domestic Animals in Central and Eastern Europe. pp. 230-296, Akadémiai Kiadó, Budapest.

4. Bökönyi, S. (1984). Horse. In : Mason, I. L. (ed.), Evolution of Domesticated Animals, pp. 162173, Longman, London and New York.

5. 済州大学校 (Cheju Univ.) (1985). 済州馬 의血統

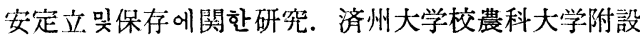
畜産問題研究所.

6. 鄭丕留 (Cheng) (1980). 我国家畜品種及其生態特 性. 6-9 頁, 農業出版社, 北京.

7. Cheng, P. (1984). Livestock Breeds of China. pp. 9-27, FAO, Rome.

8. Clutton-Brock, J. (1981). Domesticated Animals from Early Times. pp. 80-90, British Museum and Heinemann, London.

9. De Boer, L. E. M. (1979). A note on the chromosome number difference between the domestic horse and the Przewalski horse. In : De Boer, L. E. M. et al. (eds.), Genetics and Hereditary Diseases of the Przewalski Horse, pp. 97-110, Foundation for the Preservation and Protection of the Przewalski Horse, Rotterdam.

10. De France, H. F. (1979). Chromsome and evolution. In : De Boer, L. E. M. et al. (eds.), Genetics and Hereditary Diseases of the Przewalski Horse, pp. 87-95, Foundation for the Preservation and Protection of the Przewalski Horse, Rotterdam.

11. De Schepper, G. G. and De France, H. F. (1979). Chromosome analysis of the Mongolian domestic horse. A preliminary report. In : De Boer, L. E. M. et al (eds.), Genetics and Hereditary Diseases of the Przewalski Horse, pp. 85-86, Foundation for the Preservation and Protection of the Przewalski Horse, Rotterdam.

12. Dettmers, A. E., Rempel, W. E., and Comstock, R. E. (1965). Selection for small size in swine. $J$. Anim. Sci. 24 : 216-220.

13. Downs, J. F. (1961). The origin and spread of riding in the Near East and Central Asia. Amer. Anthrop. 63 : 1193-1203.

14. Eberhard, W. (1980). Geschichte Chinas. A, 
Kröner Verlag, Stuttgart. [大室幹雄，松平いを子 訳（1991）中国文明史．53-60頁，筑摩書房，東京了。

15. 江上波夫 (1967). 騎馬民族国家一日本古代史へ のアプローチ. 154-342 頁, 中央公論社, 東京.

16. Epstein, H. (1969). Domestic Animals of China. pp. 94-112, Commonwealth Agric. Bureau, London and Edinburgh.

17. FAO (1986). The Przewalski horse and restoration to its natural habitat in Mongolia. FAO, Rome.

18. Flade, J. E. (1981). Shetlandponys. A. Ziemsen Verlag, Wittenberg Lutherstadt.

19. Flade, J. E. and Glass, K. (1989). Kleinpferde. VEB Deutscher Landwirtschaftsverlag, Berlin.

20. 長谷部言人(1925). 石器時代の馬に関して. 人類 学雑誌 $40: 131-135$.

21. 林田重幸(1956). 日本古代馬の研究. 人類学雑誌 $64: 197-211$.

22. 林田重世(1957). 中幸日本の馬について。 日畜会 報 $28: 301-306$.

23. 林田重幸(1958)。 日本在来馬の系統. 日畜会報 $28: 329-334$.

24. 林田重幸(1964). 日本馬の源流. 自然 19(2)： $58-63$.

25. 林田重幸(1968). 本邦家畜の起源と系統. 日本民 族と南方文化，375-402 頁，平凡社，東京.

26. 林田重幸, 日越国吉(1961). 琉球諸島の畜産の実 態. 鹿大琉大琉球諸島共同調査報告 $1: 13-29$.

27. 林田重幸, 大塚閏一(1974). タイ国産馬の概略々 タイ国在来馬の形態. 在来家畜研究会報告 6:2837.

28. 林田重幸, 山内忠平(1955). 九州在来馬の研究. I . トカラ馬について。 日畜会報 $26: 231-236$.

29. 林田重幸, 山内忠平(1956). 九州在来馬の研究. II. 対馬の在来馬について. 日畜会報 27:13-18

30. 林田重幸, 山内忠平(1956). 九州在来馬の研究. III. トカラ馬と東亜諸地域馬の比較. 日畜会報 27 : 183-189.

31. Hayashida, S. and Yamauchi, C. (1956). Studies on the Tokara pony. Mem. Fac. Agric., Kagoshima Univ. 2: 7-15.

32. 林田重幸, 山内忠平 (1957). 馬に拈ける骨長よ り体高の推定法. 鹿児島大学農学部学術報告 6 : 146-156.

33. Herre, W. (1958). Abstammung und Domestikation der Haustiere. In: Handbuch der Tierzüchtung. I: 1-58. Paul Parey, Hamburg and Berlin.

34. Herre, W. (1972). 馬の系統分類に関する諸問題. 日畜会報 $43: 595-597$. [野澤 謙 訳〕

35. Herre, W. and Röhrs, M. (1971). Domestikation und Stammesgeschichte. In: Die Evolution der Organismen. II/2. pp. 29-174, Gustav Fischer, Stuttgart.

36. Herre, W. and Röhrs, M. (1977). Zoological considerations on the origins of farming and domestication. In: Reed, C. A. (ed.), Origins of Agriculture, pp. 245-279, Mouton Publ., The Hague and Paris.

37. Herre, W. and Röhrs, M. (1990). Haustierezoologisch gesehen. pp. 46-48, Gustav Fischer,
Stuttgart and New York.

38. 鑄方貞亮 (1945). 日本古代家畜史. 129-275頁, 河出書房, 東京.

39. 上村俊雄 (1991). 馬に関わる遺物, とくに埴輪 馬, 土馬に関する調査研究. 古代遺跡出土骨からみ たわが国の牛馬の渡来時期とその経路に関する研究 (平成 2 年度文部省科研費研究成 果 報 告 書)，147163 頁.

40. 加茂儀一 (1937). 家音文化史. 141-265頁, 改造 社, 東京.

41. 姜 冕熙 (1965). 韓国在来馬 의系統에関한 研究. 韓国畜産学会誌 $7: 92-97$.

42. 媵 冕熙 (1966). 韓国本土内의在来馬에낀한 研 究. 高麗大学校農科大学論文集 $3: 169-199$.

43. 姜 冕熙 (1970). 韓国の在来家畜について. 在 来家畜調査団報告 $4: 10-28$.

44. 河口貞徳, 西中川 駿 (1985). 鹿児島県下の貝 塚と獣骨. 季刊考古学 $11: 43-47$.

45. Keller, C. (1919). Die Stammesgeschichte unserer Haustiere. 〔加茂儀一訳 (1935). 家畜系統史. 100112頁, 岩波, 東京]

46. 金 泰能 (1969)。済州島略史. 済州年鑑〔梁聖 宗訳 (1988). 済州島略史. 54-82 頁, 新幹社, 東 京了.

47. 近藤 恵, 松浦秀治, 松井 章, 金山喜昭(1991). 野田市大崎貝塚縄文後期貝塚出土ウマ遺残のフッ素 年代判定一縄文時代にウマはいたか一. 人類学雑誌 99 : 93-99.

48. Koulischer, L. and Frechkop, S. (1966). Chromosome complement: a fertile hybrid between Equus przewalskii and Equus caballus. Science 151 : 93-95.

49. 李 基萬 (1961). 済州馬体型에関한生物統計学. 的研究. 忠南大学校農科大学.

50. Mackie, D. B. (1916). Philippine horses. J. Hered. $7: 373-382$

51. Manit, B. (1961). Notes on Thai pony. J. Thai Vet. Assoc. $12: 1-10$.

52. Mason, I. L. (1973). The role of natural and artificial selection in the origin of breeds of farm animals. Z. Tierzücht. Züchtgsbiol. 90: 229-244.

53. 松井 章 (1992). 動物遺存体から見た馬の 起源 と普及. 日本馬具大鑑，1：33-44 頁，吉川弘文館， 東京.

54. 松本久喜 (1948). 在来馬. 北方出版社, 東京.

55. 松本久喜 (1953). 北海道在来馬について. 日本 在来馬に関する研究, 15-73 頁, 日本学術振興会, 東京.

56. Matthews, J. G. and Delhanty, J. D. A. (1979). Chromosome studies in Przewalski horse (Equus przewalskii). In: De Boer, L. E. M. et al. (eds.) Genetics and Hereditary Diseases of the Przewalski Horse, pp. 71-83, Foundation for the Preservation and Protection of the Przewalski Horse, Rotterdam.

57. Merkens, J. (1926). De paarden-en runderteelt in Nederlandsch-Indie. No. 51. Veeartsenijkundige Mededeeling.

58. 三村 一 (1953). 御崎馬について. 日本在来馬 に関する研究，163-209頁，日本学術振興会，東京.

59. Mohr, E. (1970). Das Urwildpferd. A. Ziemen 
Verlag, Wittenberg Lutherstadt [Goodall, D. M. translated (1971). The Asiatic Wild Horse. J. A. Allen, London].

60. Montemayor, M. R. (1958). Half century of progress in livestock raising. Proc. 8th Pacific Sci. Congr. VI B: 303-325.

61. 森浩一編 (1974). 日本古代文化の探究「馬」. 265-293頁, 社会思想社, 東京.

62. 森 為三 (1930). 朝鮮馬の系統. 日畜会報 4： 90-112.

63. 村松 晉, 橋口 勉, 関川賢二, 田中一栄(1990). 日本在来馬の細胞遺伝学研究. 畜産試験場研究報告 $50: 1-10$.

64. 村松 育, 田中一栄, 橋口 勉, 加世田雄時朗, 茂木一重, 斉藤 勝 (1984). 日本在来馬の細胞遺 伝学的比較研究. 家畜化と品種分化に関する遺伝学 的研究 (昭和 57,58 年度文部省科研費研究成果報告 書) 37-44 頁.

65. 直良信夫 (1984). 日本馬の考古学的研究. 校倉 書房, 東京.

66. 日本馬事協会 (1981). 日本在来馬一その保存と 活用. 日本馬事協会, 東京.

67. 日本馬事協会 (1986). 野間馬に関する学術調査 報告書. 日本馬事協会, 東京.

68. 日本馬事協会 (1991). 日本在来馬の保存活用推 進のための連絡会議概要 (平成 3 年度). 日本馬事 協会, 東京.

69. 西中川 駿, 本田道輝, 松元光春 (1991). 古代 遺跡出土骨からみたわが国の牛馬の渡来時期とその 経路に関する研究. 平成 2 年度文部省科研費研究成 果報告書.

70. 西中川 駿, 上村俊雄, 松元光春 (1989). 古代遺 跡出土骨からみたわが国の牛馬の起源, 系統に関す る研究一とくに日本在来種との比較一. 昭和 63 年度 文部省科研費研究成果報告書.

71. Nobis, G. (1955). Beitrage zur Abstammung und Domestikation des Hauspferdes. Z. Tierzücht. Züchtgsbiol. 64: 201-246.

72. 野澤 謙 (1967). 琉球諸島に打ける馬. 日本在来 家畜調查団報告 $2: 34-38$.

73. 野澤 謙 (1970). 済州島馬の遺伝子構成とその系 統に関する考察. 在来家畜調査団報告 4:59-68.

74. 野澤 謙 (1971). 日本在来家畜の起源. 化学と生 物 $9: 710-718$.

75. 野澤 謙 (1975). 家畜化と集団遺伝学. 日畜会報 $46: 549-557$.

76. Nozawa, K. (1980). Phylogenetic studies on the native domestic animals in East and Southeast Asia. In: Barker, J. S. F. and Turner, H. N. (eds.), Proc. SABRAO Workshop on Animal Genetic Resources in Asia and Oceania, pp. 23-43, Tropical Agric. Res. Center, Tsukuba.

77. Nozawa, K. (1983). Blood protein variations within and between horse populations. In: Proc. 5th WCAP 2: 81-82, Japan. Soc. Zootech. Sci., Tokyo.

78. 野澤 謙 (1983). 日本の家畜とその系統. 佐々 木高明 (編), 日本農耕文化の源流，211-242頁，日 本放送出版協会, 東京.

79、野澤謙 (1986). 東扣よび東南アジア在来家畜の
起源と系統に関する遺伝学的研究. 在来家畜研究会 報告 11:1-35.

80. Nozawa, K. and Kondo, K. (1970). Gene constitution of Cheju native horse and its phylogenetic relationships with Japanese native horses. SABRAO Newsletter 2: 7-18.

81. Nozawa, K., Shotake, T., and Namikawa, T. (1975). Gene constitution and phylogenetic interrelationships among native livestock in Japan and its adjacent area, with special reference to native horses and cattle. In: JIBP Synthesis 5: 130-137. Univ. Tokyo Press, Tokyo.

82. Nozawa, K., Shotake. T., and Ohkura, Y. (1976). Blood protein variations within and between the east Asian and European horse populations. $Z$. Tierzücht. Züchtgsbiol. 93: 60-74.

83. 岡部利雄編 (1953). 日本在来馬に関する研究. 日 本学術振興会, 東京.

84. 岡部利雄 (1953). 木曾馬について. 日本在来馬 に関する研究. 74-162頁, 日本学術振興会, 東京.

85. 小山田 哄, 橋口 勉, 柳田宏一, 武富萬治 郎 (1979). トカラ馬の飼養概況および体尺測定. 鹿児 島大学農学部学術報告 $29: 99-106$.

86. Phillips, R. W., Johnson, R. G., and Moyer, R. T. (1945). The Livestock of China. pp. 18-32, U. S. Government, Washington, D. C.

87. 芝田清吾 (1969). 日本古代家畜史の研究. 100 189頁, 学術出版会, 東京.

88. 謝 成俠 (1959). 中国養馬史 [千田英二訳(1977). 中国養馬史. 日本中央競馬会弘済会, 東京].

89. Short, R. T., Chandley, A. C., Jones, R. C., and Allen, W. R. (1974). Meiosis in interspecific equine hybrids. II. The Przewalski horse/domestic horse hybrid. Cytogenet. Cell Genet. 13: 465-478.

90 . 余 長年 (Sieh) (1980). 雲南馬概説. 雲南農業大 学.

91. Sieh, C. and Wang, T. (1979). Horse breeding in China. Stud Manager's Handbook 15: 1-10.

92. 鈴木武樹編 (1975). 論集騎馬民族征服王朝説. 大 和書房, 東京.

93. 高嶺 浩 (1948). 在来馬種の体型に関する研究. 東京農林専門学校学術報告 $3: 1-26$.

94. 當山真秀 (1979). 沖縄県畜産史. 61-65頁, 那羁 出版社, 那覇.

95. 植村巻太郎 (1937). 朝鮮済州島馬の研究. 日音会 報 $10: 135-150$.

96. Volf, J. (1986). Positive and negative features of inbreeding of Przewalski horses and what do we expect from their reserves. In: The Przewalski Horse and Restoration to its Natural Habitat in Mongolia, pp. 71-74, FAO, Rome.

97. Wagner, W. (1926). Die Chinesische Landwirtschaft. [高山洋吉訳 (1972). 中国農書. 下巻 390455頁. 刀江書院, 東京].

98. 王 鉄权 (Wang) (1990). 中国矮馬資源 $(106 \mathrm{~cm})$ 及矮馬科学研究. 中国農業科学院畜牧研究所. 全国 馬匹育種委員会矮馬登記会, 北京.

99. 王 鉄权 (Wang) (1990). 中国果下矮馬. 中国農 業科学院畜牧研究所. 全国馬匹育種委員会矮馬登記 会, 北京. 
100. 山根甚信 (1943). 東印度の畜産. 14-36頁, 養賢 堂, 東京.

101. 柳田宏一, 稗田直輝, 前田芳美, 橋口 勉(1985). トカラ馬に関する研究. I . トカラ馬の体尺測定值 扣よび体重について．鹿児島大学農学部学術報告
$35: 89-95$

102. 吉田新七郎 (1926). 支那二於ケル家畜ノ研笕. 第 一篇 支那馬族, 研究. 1-9頁, 参謀本部, 東京.

103. Zeuner, F. E. (1963). A History of Domesticated Animals. pp. 299-337, Hutchinson, London. 